\title{
13
}

\section{Land Tenure and Development in Northern Australia}

\author{
Allan P. Dale, Bruce Taylor and Marcus B. Lane
}

\section{Introduction}

While principles of land ownership (predominantly freehold) under 'common law' have been relatively stable in large parts of Southern Australia, in the north there is limited freehold title and it is often clustered around major centres. Across the wider Northern Australian landscape, concepts of ownership on lands previously held by the Crown (and consequently land titles) have also changed significantly in the last 30 years, with preexisting Indigenous rights (e.g. native title) now recognised in law and new statutory forms of land rights established. Further, in recent decades Commonwealth, state and territory regulation has placed restrictions on many of the tenure rights that would otherwise have accrued with land and natural resource ownership (e.g. the Commonwealth's Environment Protection and Biodiversity Conservation Act 1999 or Queensland's Vegetation Management Act 1999).

Given this difference, land tenure is often touted by governments and industry alike as being one of the most significant barriers hindering development and investment in Northern Australia (Australian Government, 2014; Joint Select Committee on Northern Australia, 2014). Debates about land tenure in the north have been increasingly driven by economic development and, in particular, control of important resources such as minerals, prime agricultural land and conservation assets. These debates are not confined to Commonwealth, state and 
territory policy circles; there has been a significant and long-standing academic interest in tenure as a policy tool and social institution (e.g. Holmes, 2011). This work has included interest in the reform of land tenure and administration systems, with calls for greater investment in and coherence of national spatial data infrastructures underpinning land administration, particularly in federated countries like Australia where land information is generally held across multiple agencies and levels of government (Bennett et al., 2012). For example, information systems that underpin land administration are argued to be critical public good infrastructure, rather than the property of particular land administration agencies (Bennett et al., 2013).

Internationally, there has also been a long focus on human rights dimensions of the rights, responsibilities and restrictions created by land tenure policies, institutions and systems of administration (Enemark et al., 2014). In the Australian context, for example, some authors have argued that key factors underpinning Indigenous disadvantage can be characterised as 'market failure relating to the disjunction between the Indigenous land base and the broader market economy' and low levels of public investment in infrastructure on the Indigenous estate (Altman \& Dillon, 2005, p. 252). The focus has more recently turned to more specific issues of the relationship between secure tenures of home ownership and economic development on Indigenous-owned lands (Wensing \& Taylor, 2012).

Finally, there are a number of themes in the literature that are important for understanding the evolution of tenure as a policy instrument (aimed at facilitating either development or conservation) in Northern Australia's northern rangelands in particular. Holmes' (2000, 2011, 2012, 2014) significant contribution, for example, highlights pastoral leasehold tenures and native title, emphasising that tenure instruments and the administrative architecture and policy goals that govern their use are not static. Instead, they have been responsive to changing political, economic and land management requirements over time. Indeed, Holmes' work highlights how understanding tenure instruments as an evolving set of socio-legal institutions that are responsive to an everwidening suite of public policy goals, rights and interests is central to designing appropriate interventions in contemporary landscapes. This requirement for a responsive system of tenure becomes more important when we consider economic development opportunities in broader 
northern regional contexts. This is because regions in Australia's north are described as experiencing a multifunctional transition, where the mix and dominance of different values in a given landscape or region (e.g. amenity or consumptive values and conservation, Indigenous or pastoral values) are rapidly changing (Holmes, 2011, 2012). The Cape York region in particular provides stark evidence of such a rapid transition in recent decades where new regional and place identities are being formed as a result of changes to property rights, tenures and economic opportunities (Holmes, 2012).

Against this background, this chapter focuses on the relationship between tenure considerations and the broader policy concept of Northern Australian development.

\section{The Importance of Land Tenure to Northern Australian Futures}

Land tenure refers to the legal regime under which land is owned. In all states and territories of Australia there are statutory definitions of what is meant by 'land'. While the general principles of land ownership under common law have long been established, the extent of ownership has changed significantly in interpretation over the last 100 years. In particular, the rights and benefits entailed in land ownership have been interpreted, codified and, in some cases, restricted by statutory law. This has been particularly important in Northern Australia where freehold title is limited and the contention between development and conservation interests is so important. This has given rise to a concern that the potential for tenure rights to be diminished by policy and legal change has reduced the confidence of investors in the north.

In the context of Northern Australia, the focus on land tenure has been increasingly driven by matters that relate to clarifying the rights of economic and cultural development and, in particular, control over important resources such as minerals, prime agricultural and traditional lands. Consequently, Australia's land tenure systems are fundamental to several important policy domains including the resolution of historical social injustice; development planning and economic growth strategy; 
welfare, housing and employment; economic development and property markets; and natural resource, environmental and cultural management (JCU \& CSIRO, 2013).

Land ownership systems also underpin much of government policymaking and program delivery and functions such as taxation, land administration, administrative boundaries, regulation and land use management. One critical difference about the north, however, is that settlement, occupancy and land use patterns vary markedly from those in southern and eastern Australia. The Northern Australian system of land tenure was designed to expedite land settlement, secure investment in traditional agricultural development and reserve land for Indigenous and later conservation purposes (Holmes, 2000). The landscape scale consequence of this approach is that the vast majority of land (75.4 per cent) is Crown owned, two-thirds of which is pastoral leasehold (JCU \& CSIRO, 2013). Another 18.5 per cent is Indigenous land (most previously held by the Crown). Native title resolution processes continue across many parts of the crown land estate. Privately owned land accounts for only 6.1 per cent of the total area. Clearly, the proportions of Indigenous land and leasehold land are significantly higher than in Southern Australia. Native title claims and mining and gas exploration permits also cover significant parts of the landscape.

In a major reform to the purpose of the original Northern Australian system of land tenure, over 40 years ago major new tenures emerged with innovations under the Aboriginal Land Rights (Northern Territory) Act 1976, followed by the Aboriginal Land Act and Torres Strait Land Acts 1991 in Queensland. These statutes sought to provide measures of national social and land justice for Indigenous Australian and Torres Strait Islander peoples who were physically and/or legally dispossessed at the time of colonial acquisition (Hibbard et al., 2008).

As a consequence of this complexity, in recent decades, a wide range of diverse parties have advocated for change and reform to northern tenure arrangements. The more significant of these include:

- the pursuit of pastoral enterprise diversification, in some instances, via the development of irrigation, tourism or conservation on leasehold (Gleeson et al., 2012; van Etten, 2013)

- persistent interest in the expansion of agriculture in Northern Australia, particularly the expansion of irrigated cropping (Chilcott, 2009; Northern Australia Land and Water Taskforce Science Review, 2009) 
- the Council of Australian Governments (COAG) National Water Reform Agenda changed the character of water rights and access, separating water from land title, thus providing for the establishment of water markets

- major growth in the mining and gas sectors and a boom in exploration has meant that these activities are operating across a range of tenures and entitlements. This growth has also led to increased frequency of tensions related to access on rural and Indigenous lands

- native title has delivered the prospect of social reparation and tenure security for Indigenous people, while also posing legal and practical challenges as to how traditional owners can leverage investment on native title lands and other tenures

- Indigenous water interests are an emerging policy area, with new interests such as cultural flows and Strategic Indigenous Reserves being defined (NAILSMA, 2013)

- growing recognition of conservation values in northern landscapes, both within the formal conservation estate, on other tenures, and new private and not-for-profit sector investors.

There has also been a growing interest among governments, landholders and investors to seek benefits from emerging ecosystem service-based markets, in particular for carbon. Here, opportunities are being explored for banking or mitigation services and market-related knowledge services (e.g. buyers, brokers, partners and information providers) (CSIRO, 2012; Whitten et al., 2008). Researchers have reported that the negotiation of conservation or biodiversity outcomes at landscape scale on pastoral lands, for example, requires better communication with and involvement of 'new' land managers such as mining companies_-now major holders of pastoral leases in Western Australia (van Etten, 2013).

As a consequence of this history, there are several features of land tenure and its administration in the north that make it both complex and unique:

- there are multiple and often overlapping tenure types for the same area of land (e.g. the existence of non-exclusive native title rights over leasehold land)

- administrative arrangements for land tenure and classifications of similar tenure types vary across state and territory jurisdictions 
- in regions like Cape York, tenure change is happening rapidly (Holmes, 2012)

- for potential investors, multiple interactions are often required with government to gather the information needed to assess sovereign risk and to seek tenure changes

- there are numerous implications arising from the ongoing task of identifying untested native title rights

- there are emergent tenures or changes to rights related to assets such as water, carbon and biodiversity, with uncertain and evolving tenure regimes (JCU \& CSIRO, 2013).

\section{Reform Foci from the Recent Past}

There are efforts to improve tenure management arrangements within each of the north's four primary jurisdictions (see Table 13.1). For instance, each of the state and territory jurisdictions have over the last decade undertaken reviews of their own tenure arrangements, particularly with respect to pastoral leasehold lands. These recent and proposed changes aim to enable more diverse uses within tenures and to clarify access and use rights in circumstances where there are multiple entitlement holders. In addition to proposed pastoral land reforms, other recent work has focused on improving the secure allocation of water entitlements and clarifying Indigenous interests in land and water.

Reforms are also progressing in all jurisdictions in relation to land administration and land-related information management. In Western Australia, for example, progress is being made towards the creation of a Single Registration System for all Crown and freehold land (under the Land Administration Act 1996). There is also emerging national progress towards the establishment of a National Electronic Conveyancing system. 


\begin{tabular}{|c|c|c|c|}
\hline 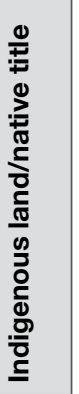 & 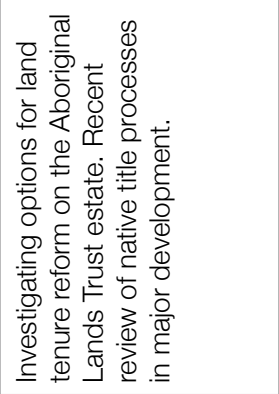 & 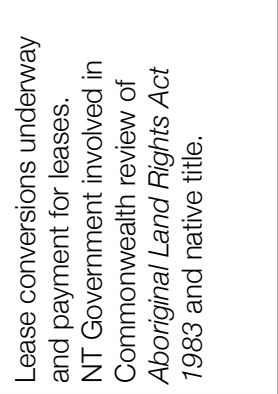 & 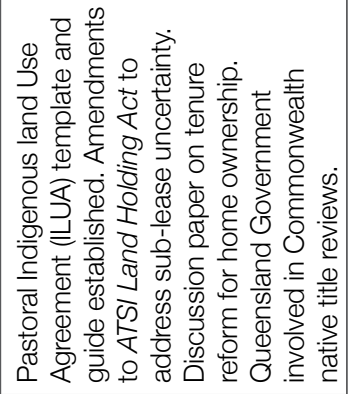 \\
\hline 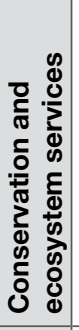 & 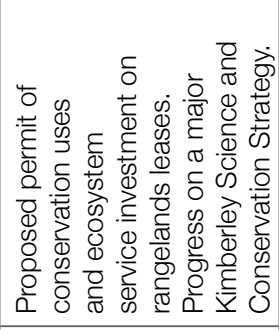 & 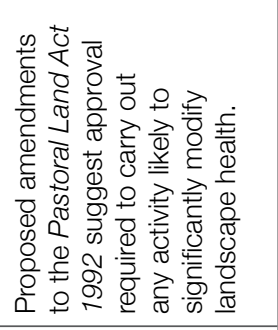 & 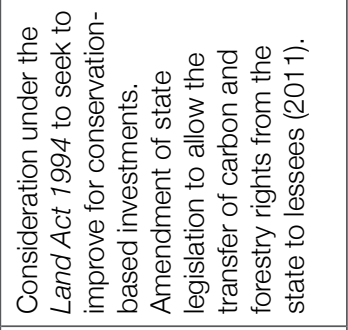 \\
\hline$\frac{\Phi}{\frac{\pi}{\pi}}$ & 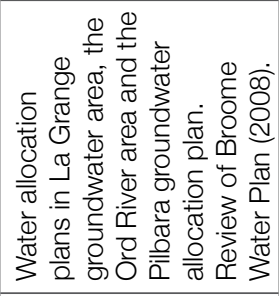 & 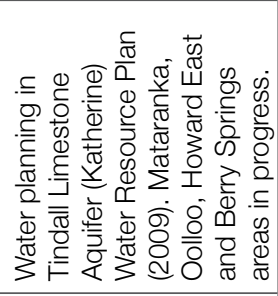 & 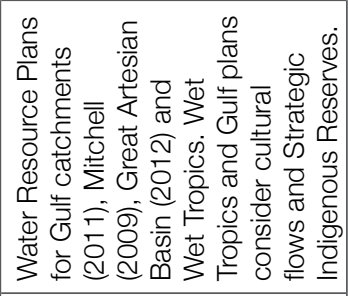 \\
\hline 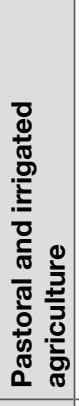 & 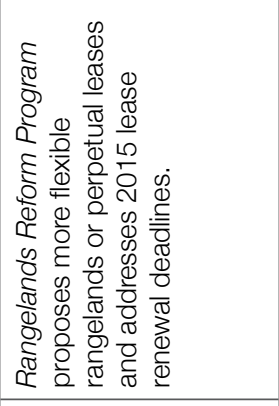 & 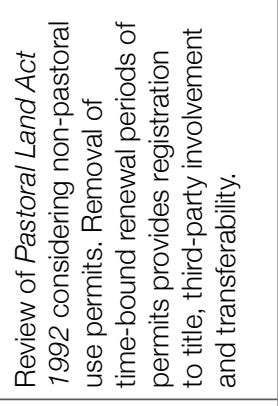 & 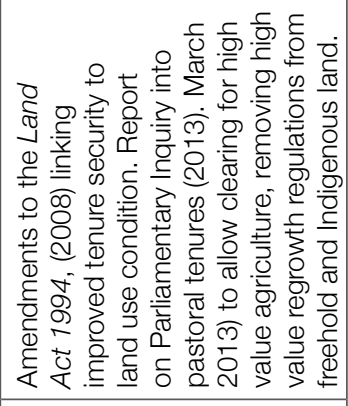 \\
\hline 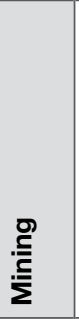 & 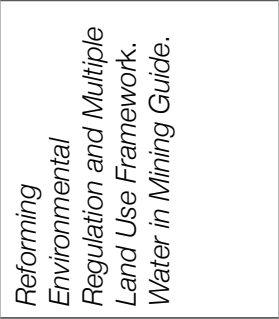 & 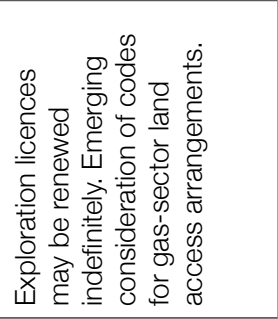 & 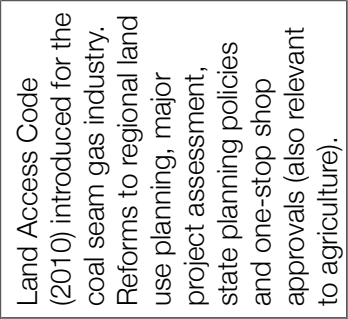 \\
\hline & $\$$ & 乞 & $\frac{\overline{0}}{\bar{O}}$ \\
\hline
\end{tabular}




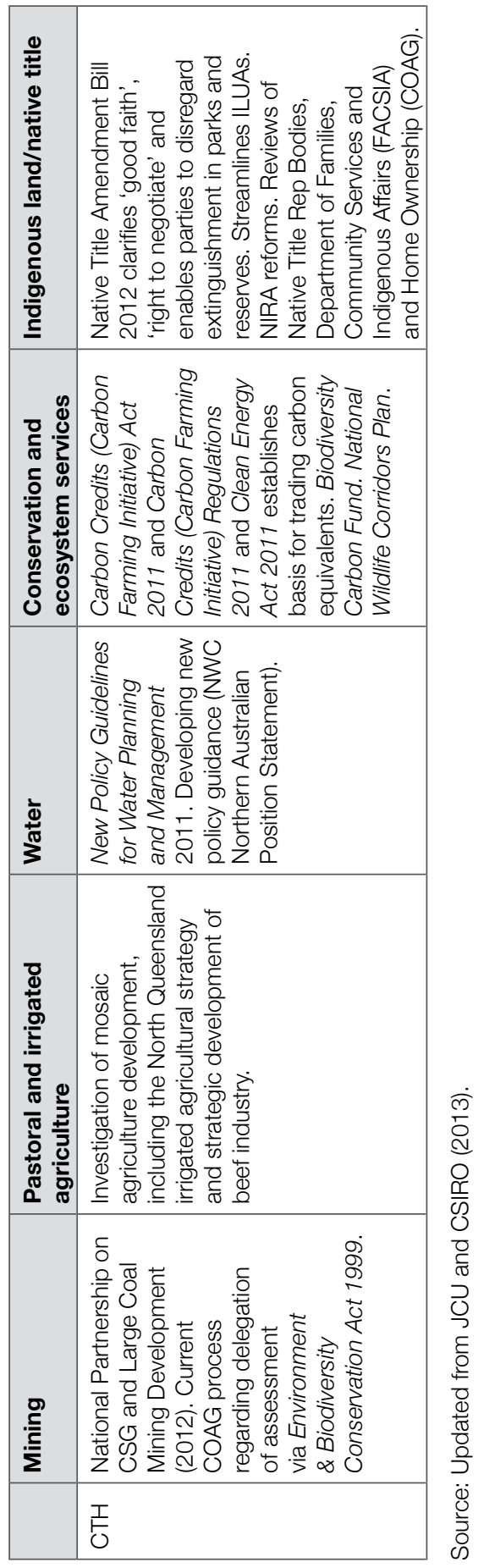




\section{Opportunities for Tenure Reform and Barriers for Progression}

The opportunity for reform in land tenure to drive diverse investment in the sustainable development of Northern Australia is significant. Such changes might serve to reduce conflict and encourage more optimal use and management of the north's natural resources, while also protecting the rights of interests of traditional owners. Potential new reforms could also enable land owners to manage and trade vital ecosystem services such as water, biodiversity and carbon while providing additional economic development opportunities. Based on wide discussion across key Northern Australian stakeholders, JCU and CSIRO's (2013) report to the Northern Australia Ministerial Forum (NAMF) proposed a number of broad areas of focus for realising these opportunities in the short, medium and long terms. Table 13.2 provides a summary of the individual opportunity that might be actioned and the feasibility and benefit likely to be derived over time.

Table 13.2: Key opportunities for improving land tenure arrangements in Northern Australia.

\begin{tabular}{|c|c|c|c|c|c|}
\hline \multirow[t]{2}{*}{ Opportunity } & \multirow[t]{2}{*}{ Feasibility } & \multirow[t]{2}{*}{ Benefit } & \multicolumn{3}{|c|}{ Timescale } \\
\hline & & & $1 \mathrm{yr}$ & $2-5$ yrs & $>5$ yrs \\
\hline \multicolumn{6}{|l|}{ Tenure improvements } \\
\hline $\begin{array}{l}\text { Harmonise key tenure-related } \\
\text { practices across jurisdictions }\end{array}$ & $\mathrm{H}$ & $\mathrm{H}$ & & $\checkmark$ & \\
\hline $\begin{array}{l}\text { Provide a single 'whole of } \\
\text { government' point of contact for } \\
\text { tenure resolution }\end{array}$ & M & M & & $\checkmark$ & \\
\hline $\begin{array}{l}\text { Adopt consistent principles to } \\
\text { improve flexibility and diversify land } \\
\text { use especially on pastoral and } \\
\text { Indigenous lands }\end{array}$ & $\mathrm{H}$ & $\mathrm{H}$ & $\checkmark$ & & \\
\hline $\begin{array}{l}\text { Complete rollout of National Water } \\
\text { Initiative principles and statutory } \\
\text { water plans across the north }\end{array}$ & $\mathrm{H}$ & $\mathrm{H}$ & & & $\checkmark$ \\
\hline $\begin{array}{l}\text { Develop and implement a consistent } \\
\text { approach to Indigenous water } \\
\text { including rights to water for } \\
\text { commercial purposes }\end{array}$ & $\mathrm{H}$ & $\mathrm{H}$ & & $\checkmark$ & \\
\hline $\begin{array}{l}\text { Ensuring consistency of tenure } \\
\text { arrangements for carbon/biodiversity } \\
\text { in the landscape }\end{array}$ & $\mathrm{H}$ & M & & $\checkmark$ & \\
\hline
\end{tabular}




\begin{tabular}{|c|c|c|c|c|c|}
\hline \multirow[t]{2}{*}{ Opportunity } & \multirow[t]{2}{*}{ Feasibility } & \multirow[t]{2}{*}{ Benefit } & \multicolumn{3}{|c|}{ Timescale } \\
\hline & & & $1 \mathrm{yr}$ & $2-5$ yrs & $>5$ yrs \\
\hline $\begin{array}{l}\text { Continuous improvement in } \\
\text { progressing native title/statutory } \\
\text { claims }\end{array}$ & M & $\mathrm{H}$ & & & $\checkmark$ \\
\hline $\begin{array}{l}\text { Provide more flexible means } \\
\text { of transition from leasehold to } \\
\text { freehold on small land parcels for } \\
\text { intensive uses }\end{array}$ & M & $\mathrm{H}$ & & $\checkmark$ & \\
\hline \multicolumn{6}{|c|}{ Information, planning and major project assessment } \\
\hline $\begin{array}{l}\text { Develop a nationally-consistent } \\
\text { and spatially explicit tenure (and } \\
\text { registered interests) data system }\end{array}$ & $\mathrm{H}$ & M & $\checkmark$ & & \\
\hline $\begin{array}{l}\text { Reduce project delays by improving } \\
\text { development assessment practice }\end{array}$ & M & $\mathrm{H}$ & & $\checkmark$ & \\
\hline $\begin{array}{l}\text { Initiate stable, regionally-scaled } \\
\text { strategic land and resource use } \\
\text { planning }\end{array}$ & M & M & & & $\checkmark$ \\
\hline
\end{tabular}

Note: $\mathrm{H}=$ High and $\mathrm{M}=$ Medium .

Source: Updated from JCU and CSIRO (2013).

While different sectors and interests across Northern Australia face distinct investment issues, stakeholder engagement undertaken in the development of JCU and CSIRO's (2013) report to the NAMF identified common and significant tenure-related barriers to investment (see Table 13.3). These include the underlying complexity of tenures and entitlements on a given area of land, the capacity for investors to manage across multiple tenures and jurisdictions and resolve disputes efficiently, and the limits of some types of tenure to allow owners to leverage land assets for capital and development purposes such as on some Indigenous tenures. It is also important to understand that while tenure is an important consideration, it is only one of a number of factors that may impede investment. Infrastructure, distance to market, land values and terms of trade all have significant weight in investment decisions. 
Table 13.3: Tenure-related impediments to investment as they relate to different sectors and interests.

\begin{tabular}{|c|c|c|c|}
\hline \multicolumn{2}{|l|}{ Impediments } & \multirow{2}{*}{$\frac{\text { Frequency }}{\mathrm{H}}$} & \multirow{2}{*}{$\frac{\text { Impact }}{M}$} \\
\hline Mining & $\begin{array}{l}\text { Delays converting and establishing extraction } \\
\text { permits }\end{array}$ & & \\
\hline & $\begin{array}{l}\text { Negotiation of native title agreements } \\
\text { and access }\end{array}$ & $\mathrm{H}$ & M \\
\hline & $\begin{array}{l}\text { Inconsistent water pricing regimes and } \\
\text { securing water access }\end{array}$ & $\mathrm{H}$ & $\mathrm{M}$ \\
\hline & $\begin{array}{l}\text { Negotiating single projects across complex } \\
\text { multiple tenures }\end{array}$ & M & $\mathrm{M}$ \\
\hline & $\begin{array}{l}\text { The non-tax-exempt status of native title } \\
\text { payments }\end{array}$ & $\mathrm{M}$ & $\mathrm{M}$ \\
\hline \multirow[t]{7}{*}{$\begin{array}{l}\text { Pastoral and } \\
\text { agriculture }\end{array}$} & $\begin{array}{l}\text { Poor flexibility to diversify and realign } \\
\text { boundaries }\end{array}$ & $\mathrm{H}$ & $\mathrm{H}$ \\
\hline & $\begin{array}{l}\text { Uncertainty with lease renewal processes/term } \\
\text { security }\end{array}$ & $\mathrm{H}$ & $\mathrm{H}$ \\
\hline & $\begin{array}{l}\text { Lease rental policy not aligned to land } \\
\text { productivity }\end{array}$ & $\mathrm{M}$ & $\mathrm{H}$ \\
\hline & $\begin{array}{l}\text { Native title 'Future Act' triggers are unclear/ } \\
\text { third-party respondent funding }\end{array}$ & $\mathrm{H}$ & $\mathrm{H}$ \\
\hline & $\begin{array}{l}\text { Multiple tenures and limitations on who can } \\
\text { hold a lease }\end{array}$ & M & M \\
\hline & Insecurity due to exploration and mining rights & M & M \\
\hline & $\begin{array}{l}\text { Limited system of vendor disclosure of } \\
\text { government land interests }\end{array}$ & $\mathrm{L}$ & $\mathrm{L}$ \\
\hline \multirow{4}{*}{$\begin{array}{l}\text { Conservation } \\
\text { and } \\
\text { ecosystem } \\
\text { services }\end{array}$} & $\begin{array}{l}\text { Some pastoral lease conditions inhibit } \\
\text { conservation }\end{array}$ & $\mathrm{H}$ & M \\
\hline & $\begin{array}{l}\text { Costs, restrictions and uncertainties to change } \\
\text { lease conditions }\end{array}$ & M & M \\
\hline & $\begin{array}{l}\text { Legislative inconsistency on carbon rights } \\
\text { between jurisdictions }\end{array}$ & $\mathrm{L}$ & M \\
\hline & $\begin{array}{l}\text { Resumption of rights and issuing of third party } \\
\text { rights on Nature Refuges }\end{array}$ & $\mathrm{L}$ & $\mathrm{H}$ \\
\hline \multirow[t]{4}{*}{ Water } & $\begin{array}{l}\text { Nascent status of National Water Initiative-- } \\
\text { compliant water plans }\end{array}$ & $\mathrm{H}$ & $\mathrm{L}$ \\
\hline & $\begin{array}{l}\text { Unresolved Indigenous rights with respect } \\
\text { to water }\end{array}$ & M & $\mathrm{L}$ \\
\hline & $\begin{array}{l}\text { Cross-basin trading can be inconsistent with } \\
\text { Indigenous values }\end{array}$ & $\mathrm{L}$ & $\mathrm{L}$ \\
\hline & Inadequate water data and mapping & M & M \\
\hline
\end{tabular}




\begin{tabular}{|c|c|c|c|}
\hline \multicolumn{2}{|l|}{ Impediments } & Frequency & Impact \\
\hline \multirow{5}{*}{$\begin{array}{l}\text { Traditional } \\
\text { owners and } \\
\text { Indigenous } \\
\text { home } \\
\text { ownership }\end{array}$} & $\begin{array}{l}\text { Unresolved native title and other land and } \\
\text { sea claims }\end{array}$ & $\mathrm{H}$ & $\mathrm{H}$ \\
\hline & Lack of finance leveraging capacity on tenures & $\mathrm{H}$ & $\mathrm{H}$ \\
\hline & $\begin{array}{l}\text { Lack of guarantee for mortgaging associated } \\
\text { with inalienability }\end{array}$ & $\mathrm{H}$ & $\mathrm{H}$ \\
\hline & $\begin{array}{l}\text { Uncertain process for government-leasing } \\
\text { of native title lands }\end{array}$ & M & $\mathrm{H}$ \\
\hline & $\begin{array}{l}\text { Insufficient or crude registration of Indigenous } \\
\text { tenures }\end{array}$ & $\mathrm{L}$ & $\mathrm{L}$ \\
\hline
\end{tabular}

Note: $\mathrm{H}=$ High, $\mathrm{M}=$ Medium and $\mathrm{L}=\mathrm{Low}$.

Source: JCU and CSIRO (2013).

\section{New Directions in Tenure Management}

The case for improving tenure arrangements in Northern Australia is compelling, but the challenge in doing so is substantial, requiring significant cross-jurisdictional cooperation and national investment in research and development. It will not happen quickly. JCU and CSIRO's (2013) report to the NAMF proposed that efforts to reduce impediments to investment and development in Northern Australia might be pursued in three distinct ways. The first is attending to tenure complexity through administrative or legislative reform. This could involve supporting collaborative research and policy development partnerships on critical issues of investment and financing on Indigenous tenures, developing consistent principles to guide tenure reviews in the different jurisdictions and improving the quality and accessibility of tenure-related data for northern regions. The second main pathway involves improving the efficiency of development assessment and regulation, including clarifying major project assessment responsibilities between jurisdictions, better resourced negotiation and streamlined administration of assessment processes and resources to assist with tenure-resolution processes that arise following project approval. The third main pathway could focus on actions to improve the effectiveness of land and resource (including water) planning so that broader 'regional'- or 'landscape'-level signals exist about the preferred infrastructure and resource use futures for different northern regions. Such planning would provide the broader context in which locallevel conflicts over tenure can be resolved. 
Tenure reform in the north, however, must preserve the rights of and create opportunities for the north's traditional owners. Tenure is implicated in the ongoing social and economic disadvantage suffered by Indigenous people. Indigenous-led tenure reform on Indigenous tenures, therefore, has a role to play in ameliorating this situation. Finding the means by which traditional owners can leverage their land assets to raise capital for social and economic development offers great national and local benefit. However, this needs to be able to accommodate informed consent and the inalienability of title. In considering these issues (see also NAILSMA, 2013), support is required to progress policy options which will have general applicability to traditional owners across Northern Australia. Such work could focus on:

- progressively resolving ongoing native title/land claim issues and water rights

- supporting and resourcing the capacity of traditional owners to develop country-based/land use planning across their estate, township-based land use planning and wealth generation strategies

- exploring further the most appropriate tenure and financial mechanisms for facilitating investment leverage (within Indigenous land estates)

- supporting traditional owners to explore new and innovative governance models for managing aspirational/country-based planning and 'wealth funds' emerging from economic development

- exploring some form of Northern Australian 'guarantee or trust fund' to support traditional owners with sound business investment projects to secure commercial finance, funded either from amendment to existing or new government funds, private sector investment or innovative investment of local traditional owner-based sovereign wealth funds at the local scale

- pan-northern partnering with lending institutions to build investment confidence.

Given the complexity and diversity that exists within land tenure arrangements in Northern Australia described above, it would be understandable to presume the goals of efficiency and consistency are paramount in the quest for improving opportunities for investment. However, many of the most significant gains in terms of improving investor certainty and improving development outcomes for northern enterprises and communities will come from engaging with this complexity in constructive and more informed ways that recognise the unique mix of land uses, resources, rights and interests in northern lands. 


\section{Acknowledgements}

Much of this work was originally supported by the Australian Government within the context of the North Australia Ministerial Forum. It was also supported by the Department of Industry, Innovation, Science, Research and Tertiary Education via the Northern Futures Collaborative Research Network, the Australian Government's Stream 2 Climate Adaptation Program and the Australian Research Council. We would also like to thank Andrew Johnson for his leading contributions to the original JCU and CSIRO (2013) report and the wide range of contributors, practitioners and experts from across Northern Australia consulted during that process.

\section{References}

Altman, J. \& Dillon, M. (2005). Commercial development and natural resource management on the Indigenous estate: A profit related investment proposal. Economic Papers, 24(3), 249-262. doi.org/10.1111/j.1759-3441. 2005.tb00377.x

Australian Government. (2014). Green paper on developing northern Australia. Canberra, ACT: Department of the Prime Minister and Cabinet. Retrieved from www.industry.gov.au/sites/default/files/2019-09/green-paperon-developing-northern-australia.pdf

Bennett, R., Rajabifard, A., Williamson, I. \& Wallace, J. (2012). On the need for national land administration infrastructures. Land Use Policy, 29, 208-219. doi.org/10.1016/j.landusepol.2011.06.008

Bennett, R., Tambuwala, N., Rajabifard, A., Wallace, J. \& Williamson, I. (2013). On recognizing land administration as critical, public good infrastructure. Land Use Policy, 30, 84-93. doi.org/10.1016/j.landusepol.2012.02.004

Chilcott, C. (2009). Growing the north - Opportunities and threats to developing agriculture in the north of Western Australia. Farm Policy Journal, 6(2), 11-17.

Commonwealth Scientific and Industrial Research Organisation (CSIRO). (2012). The emerging carbon economy for Northern Australia: Challenges and opportunities. Canberra, ACT.

Enemark, S., Hvingel, L. \& Galland, D. (2014). Land administration, planning and human rights. Planning Theory, 13(4), 331-348. doi.org/10.1177/1473 095213517882 
Gleeson, T., Martin, P. \& Mifsud, C. (2012). Northern Australian beef industry: Assessment of risks and opportunities. ABARES report to client prepared for the Northern Australia Ministerial Forum (ABARES project 43220). Canberra, ACT: ABARES.

Hibbard, M., Lane, M. B. \& Rasmussen, K. (2008). The split personality of planning: Indigenous people and planning for land and resource management. Journal of Planning Literature, 23(2), 136-152. doi.org/10.1177/08854122 08322922

Holmes, J. (2000, 21-22 February). Land tenure and administration in Northern Australia: Needed future directions. Paper presented at the Tropical Savannas CRC Forum: Land Administration and Management in the Tropical Savannas: A Better Way, Darwin, Australia.

Holmes, J. (2011). Land tenures and policy instruments: Transitions on Cape York Peninsula. Geographical Research, 49(2), 217-233. doi.org/10.1111/ j.1745-5871.2011.00692.x

Holmes, J. (2012). Cape York Peninsula, Australia: A frontier region undergoing a multifunctional transition with Indigenous engagement. Journal of Rural Studies, 28, 252-265. doi.org/10.1016/j.jrurstud.2012.01.004

Holmes, J. (2014). Explorations in Australian legal geography: The evolution of lease tenures as policy instruments. Geographical Research, 52(4), 411-429. doi.org/10.1111/1745-5871.12083

James Cook University (JCU) \& Commonwealth Scientific and Industrial Research Organisation (CSIRO). (2013). Land tenure in Northern Australia: Opportunities and challenges for investment. Brisbane, QLD: CSIRO.

Joint Select Committee on Northern Australia. (2014). Pivot North: Inquiry into the development of Northern Australia - Final report. Canberra, ACT: Australian Government. Retrieved from www.aph.gov.au/Parliamentary_Business/ Committees/Joint/Former_Committees/Northern_Australia/Inquiry_into _the_Development_of_Northern_Australia/Tabled_Reports

North Australian Indigenous Land and Sea Management Alliance (NAILSMA). (2013). Indigenous futures and sustainable development in north Australia: Towards a framework for full Indigenous participation in economic development (Discussion paper 018/2013). Darwin, NT: NAILSMA.

Northern Australia Land and Water Taskforce Science Review. (2009). Northern Australia land and water science review 2009: Full report. Darwin, NT: Australian Government. 
van Etten, E. J. B. (2013). Changes to land tenure and pastoral lease ownership in Western Australia's central rangelands: Implications for co-operative, landscapescale management. The Rangeland Journal, 35(1), 37-46. doi.org/10.1071/ RJ11088

Wensing, E. \& Taylor, J. (2012). Secure tenure for home ownership and economic development on land subject to native title (Australian Institute of Aboriginal and Torres Strait Islander Studies research discussion paper no. 31). Canberra, ACT: AIATSIS.

Whitten, S., Abel, N. \& Cowell, S. (2008). A scoping study of the market-based opportunities available to eco-entrepreneurs in the rangelands. Report prepared for Bush Heritage Australia. Canberra, ACT: CSIRO Sustainable Ecosystems. 
This text is taken from Leading from the North: Rethinking Northern Australia Development, edited by Ruth Wallace, Sharon Harwood, Rolf Gerritsen, Bruce Prideaux, Tom Brewer, Linda Rosenman and Allan Dale, published 2021 by ANU Press, The Australian National University, Canberra, Australia. 